\title{
The Analysis of the Impacts of Housing Price Fluctuation on Residents' Consumption in Our Country
}

\author{
Qian-Wen Zhang \\ School of Economics, Shanghai University, P.R. China \\ Email: 576817840@qq.com
}

\author{
Feng Shen \\ NO.99 Shangda Road, Baoshan district, Shanghai, China
}

\begin{abstract}
In this article, we took the 24 region as the research object, selected the annual data from 2000 to 2014, and set up a panel data model, to analyze how the price fluctuations influence the major urban resident consumption from the wealth effect and crowding out effect. Research shows that the rise of house price will lead to a rise trend in consumer demand, Put forward a certain theoretical basis for our government's real estate control policies. The innovation of this article is showing the impact of changes in housing prices on the consumptions of residents from the perspectives of income effect and wealth effect, and the model is analyzed by using the panel data.
\end{abstract}

Keywords- House Price, Consumer Demand, Policy Suggestion.

\section{INTRODUCTION}

The real estate market is an important part of Chinese economic market, and it is also an important market related to the living standard of our country, from the implementation of commercial housing policy so far, Chinese real estate industry has been in a stage of rapid development, meanwhile, Cities' real estate industry has also developed a lot, for example, Our resident housing average selling prices rose from 2197 yuan/square in 2003 to 5430 yuan/square in 2012, increased about 1.5 times. Then, such a high estate price growth, whether it will cause a certain impact on the consumption of urban residents, This paper mainly discusses the problem is how the price fluctuations influence the major urban residents consumption.

\section{LITERATURE REVIEW}

Tang Zhijun(2010):Pointed out that the extrusion effect is greater than the wealth effect because of rising house prices, it will suppress the current consumption. Through the cointegration test and VAR analysis can find that the real estate price fluctuations will have a negative impact on total retail sales of social consumer goods.

CaloMirisetal: Using the data, by after controlling endogenous problems as the housing wealth and the permanent income, get that housing wealth effect is very smalland was not significant.

$\mathrm{Li}$ and Yao(2007): Based on the life cycle-- permanent income hypothesis to analyze house prices influence on youth and old aged landlord, and find that the increase of house prices will increase the welfare of the old landlord but it will have negative influence on young renter and young landlord. At the same time it is not good for people who need to buy house.

Sheiner(1995) research find: House prices up volatility means young renters must reduce current consumption, increase savings to make the plan of purchasing house. Even if the families of the housing increased consumption because of rising house prices, while this may increase of consumption and renters for future buying plans to increase savings phase offset, which may cause the whole demand of society do not change.

Friedman proposed the permanent income hypothesis in 1957.He divided consumers' income into temporary income and permanent income, and divided consumers' spending into temporary spending and permanent spending. There is a fixed ratio relationship between permanent income and durable consumption. Therefore, consumers' spending is not mainly determined by his current income, but by his long lasting income.

\section{THE ANALYSIS OF THE STATUS QUO OF HOUSING PRICES}

Since the system of resident's housing has experienced innovation, then the market of the real estate in our country developed quickly, housing has been commercialized, and its investment properties has been brought to the attention of the developers. Real estate investment increased year by year, at 2012,investment has reached 7.1804 trillion, compared with 251.33 billion in 1998, it increased by 19.86 times, the average annual growth of $23.94 \%$. When the real estate industry in prosperous development, China's urban resident housing prices also climb rapidly. Our resident housing average selling prices rose from 2197 yuan/square in 2003 to 5430 yuan/square in 2012, increased about 1.5 times. 
TABLEI REGIONAL AVERAGE HOUSE PRICES IN CHINA [UNITS:YUAN/SQUARE METRE]

\begin{tabular}{|c|c|c|c|c|}
\hline Year & $\begin{array}{c}\text { Average house prices in the } \\
\text { east }\end{array}$ & $\begin{array}{c}\text { Average house prices in the } \\
\text { central region }\end{array}$ & $\begin{array}{c}\text { Average house prices in the } \\
\text { west }\end{array}$ & $\begin{array}{c}\text { Average house prices } \\
\text { in China }\end{array}$ \\
\hline 2002 & 2556.91 & 1427.13 & 1550.92 & 2250 \\
\hline 2003 & 2759.64 & 1501.75 & 1589.75 & 2359 \\
\hline 2004 & 3117.40 & 1685.56 & 1788.75 & 3167.65 \\
\hline 2005 & 3903.39 & 1962.64 & 1923.35 & 3366.79 \\
\hline 2006 & 4452.29 & 2089.89 & 2063.85 & 3863.90 \\
\hline 2007 & 5388.73 & 2412.42 & 2451.36 & 3800 \\
\hline 2008 & 5656.91 & 2552.63 & 2626.42 & 4681 \\
\hline 2009 & 6848.82 & 2975.75 & 2946.42 & 5032 \\
\hline 2010 & 8185.45 & 3516.63 & 3425.83 & 5357.1 \\
\hline 2011 & 8576.60 & 4058.03 & 3916.86 & \\
\hline
\end{tabular}

Data source: 2005-2014China Statistical Yearbook

As the statistical data showed in the table, now, under the influence of our country housing supply and demand factors, house price presented rise year by year, and on the whole it has a rising trend in the future. Recent years, the overall comprehensive index of estate market still rising in China. Although the government has made some measures to against the rising house prices, the price still very high. With the intensification of the urbanization process, the number of town dweller increasing year by year, there are more than millions of population migration move to city each year, which caused the residents' rigid demand for housing in cities for a long time, and the demand is increasing. At the same time, the supply of urban housing is limited, which can't meet the large demand of urban population. The investors strength the investment in real estate market to benefit from it, and the residents who have more than one real estate get funds through the form of rent. This kind of unbalanced supply and demand situation, greatly promote the housing price has soared, which caused the current situation of the housing prices continue to rise and bring tremendous pressure to residents who need to buy house.

In theory, the rise of house price and the situation in which housing demand in short supply will lead crowding out effect on residents' consumption, thus resulting in lower consumer demand. But, now as people's living standards continue to improve, residents' financial capacity has been greatly improved than before, resident will not only save money and invest in stocks, real estate, etc. as well. Thus, for those residents who invest in real estate, with the rise of house prices, these people will enjoy more wealth effects and under this circumstance will increase the consumption demand of residents.

\section{THE EMPIRICAL RESEARCH}

\section{A. The Specification of Model}

First through the establishment of residents' consumption and wealth derived from the utility optimization model of estimating equations, to assume the consumption of the utility function as:

$$
U\left(C_{t}\right)=\frac{C_{t}^{1-\theta}}{1-\theta}
$$

$\mathrm{Ct}$ expression the consumption of the $\mathrm{t}$, use $\delta$ as the utility rate of discount. Under the case of uncertainty, establish the consumers expect total utility optimization model as:

$$
C_{t} \sum_{t=0}^{\operatorname{Max}} \frac{U\left(C_{1+t}\right)}{(1+\delta)^{t}}=E_{t} \sum_{t=0}^{T-t} \frac{C_{t}^{1-\theta}}{(1-\theta)(1+\delta)^{t}}
$$

$$
S . T . \sum_{t=0}^{T-t} \frac{\left(Y_{1+t}-C_{1+t}\right)}{(1+r)^{t}}=W_{t}
$$

$Y_{1+t}$, Wt represent the income in $1+\mathrm{t}$ and the wealth in $\mathrm{t}$ respectively, represent the discount rate of assets, $\mathrm{T}$ shows the length of the life.

According to the optimization of first-order conditions 、 the utility function of the first-order countdown, take expectations of constraint conditions, we can get the basic model of the article as: 


$$
C_{t}=c Y_{t}+k W_{t}
$$

$C_{t}, Y_{t}, W_{t}$ means consumption, income and wealth in the time of $t$ respectively. This model is consistent with the three theoretical models, contains the Friedman's permanent income theory, Franco Modigliani lifecycle model and LC-PIH model about the consumption decided by income and wealth. House, as the important part of wealth, can use this model to assess the increase of house prices impact on consumption.

\section{B. Variable Selection}

This article selects the Chinese 35 large and medium-sized cities with urban development and typical properties as sample, in these 35 cities most are deputy provincial city, the development speed is fast. These cities covered the east 、entral and western regions, and the proportion of city is proportional to the economic development. $\mathrm{C}$ is showed as $\mathrm{CP}, \mathrm{Y}$ is showed as PI, W is showed as average price of house HP and the investments in real estate HI. Variable being explained: $\mathrm{CP}$, explanatory variable: PI, HP and the average consumption of urban residents last time $(\mathrm{LCP}(-1))$.

In order to reduce the effects of data heteroscedasticity regression estimation results, this paper adopts the exponential form.

$$
L n C P_{i t}=\alpha_{i}+\beta_{1} L n P I_{i t}+\beta_{2} L n H P_{i t}+\beta_{3} L n C P_{i(t-1)}+\epsilon_{i t}
$$

\section{Regression Estimate}

In general case, before we carry out on the panel data regression, we need to deal with the data of stationarity and cointegration test. But this article use the data with short span, so do not need do the test. We need to use the panel data model to do the analyze, which can be classified as random effects model and fixed effect model. In order to determine what kind of model should be taken in this paper, we need to conduct Hausman test to test whether it fit for random effects model.

One core assumptions of Hausman test is that the null hypothesis is a random effect, which is no contact with explanatory variable and fixed effect estimator $\hat{\beta}_{F E}$ is consistent with random effects $\hat{\beta}_{R E}$.

That is: $H_{0}: \hat{\beta}_{F E}=\hat{\beta}_{R E}$

Hausman test verify the two estimators whether there was a significant difference, if can't reject the null hypothesis, then use random effects model; if reject, use fixed effect model. Use eviews 6.0 to do the Hausman test, we can get the result as:

TABLEII THE CONSEQUENCE OF HAUSMAN TEST

\begin{tabular}{|c|c|c|}
\hline Test summary & Chi-Sq. statistic & Prob. \\
\hline Cross-section & 17.243564 & 0.0041 \\
\hline
\end{tabular}

From the result, we can reject the null hypothesis, so we establish fixed effect model.

According to fixed effect variable intercept model, we can get the result as follow:

TABLEIII THE CONSEQUENCE OF FIXED EFFECT MODEL

\begin{tabular}{|c|c|c|c|c|}
\hline Variable & Coefficient & Std. Error & t-Statistic & Prob. \\
\hline C & 0.360243 & 0.043718 & 8.240157 & 0 \\
\hline LnPI & 0.420063 & 0.028983 & 14.49332 & 0 \\
\hline LnHP & 0.023902 & 0.013161 & 1.816136 & 0.07 \\
\hline LnCP(-1) & 0.510843 & 0.031588 & 16.17201 & 9.141929 \\
\hline R-squared & 0.995336 & Mean dependent war & 0.480837 \\
\hline Adjusted R-squared & 0.994979 & S.D. dependent war & -3.85041 \\
\hline S.E. of regression & 0.034071 & Akaike info criterion & -3.54755 \\
\hline Sum squared resid & 0.500331 & Schwarz criterion & -3.7312 \\
\hline Log likehood & 929.22 & Hannan-Quinn criter & 1.716781 \\
\hline F-statistic & 2787.338 & Durbin-Watson stat & 0.000000 \\
\hline Prob(F-statistic) & \multicolumn{3}{|c|}{} \\
\hline
\end{tabular}

From the result, we can get estimation results of model: $L n C P_{i t}=0.360243+0.420063 \operatorname{LnPI}_{i t}+0.023902 \operatorname{LnHP}_{i t}+0.510843 \operatorname{LnCP}_{i(t-1)}$
$R^{2}=0.995336, \quad \bar{R}^{2}=0.994979$ are very high, and concomitant probability of F test is 0.000000 , which is mean that there is highly linear between variables.

Fixed effect $\alpha_{i}{ }^{*}$ is showed as following: 


\begin{tabular}{|c|c|c|c|c|c|}
\hline _AH--C & -0.00333 & _HUN--C & 0.0093 & _SC--C & 0.025573 \\
\hline _BJ--C & 0.000273 & _JL-CC & 0.019015 & _TJ--C & 0.004131 \\
\hline _FJ--C & -0.01231 & JS--C & -0.02479 & _XZ--C & -0.01736 \\
\hline _GS--C & 0.018467 & _JX-C & -0.03614 & _XJ--C & 0.014005 \\
\hline _GD--C & 0.030352 & _LN--C & 0.053224 & _YN--C & -0.01803 \\
\hline _GX--C & -0.02935 & _NMG--C & 0.033899 & _ZJ--C & -0.00829 \\
\hline _GZ--C & -0.01338 & _NX--C & 0.019359 & _CQ--C & 0.038173 \\
\hline _HN--C & -0.01611 & _QH--C & 0.001003 & & \\
\hline _HB--C & -0.03364 & _SD--C & -0.02957 & & \\
\hline _HAIN--C & -0.02441 & _SX--C & -0.03854 & & \\
\hline _HLJ--C & -0.00173 & _SHX--C & 0.02814 & & \\
\hline _HUB--C & 0.00333 & _SH-C & 0.00872 & & \\
\hline
\end{tabular}

From the result, we can know that the rise of house price will lead to a rise trend in consumer demand.

\section{POLICY SUGGESTIONS}

According to the empirical results, we can know that even in the face of huge pressure on the mortgage, the rise of house price still lead to wealth effect, That is, the rise in housing prices will promote the rise in the level of consumer spending. But, at present, China's housing prices are rising very rapidly, and most of the urban residents in our country are facing huge pressure of housing loans, the situation cause these people not to to consume but to save money to pay the mortgage ,thus the wealth effect of rising house prices has been reduced. Imperfect housing security system, will cause China's economic disorder, and the collapse at last. Therefore, in order to enhance the level of consumer demand for urban residents in our country, we should improve the housing security system, control the growth rate of housing prices of urban residents, and regulate the behavior of our country's housing market.

The housing secondary market refers to the private ownership of housing rental, sales and other activities in the market. In this trading market, the main subject is the housing property owners and consumers purchasing activities. The development of housing secondary market is the safe guard for estate market to develop healthy, is good for the prosperity of the primary market. At the same time, the housing secondary market can meet the demand of different people for house. While if the housing secondary market is lack of standardization, it will hinder the real estate market liquidity in our country and is not good for the stable growth of economic.

We must establish a public secondary market system to improve secondary market of estate, usually agency or seller will obtain more comprehensive information than buyers in the process of buying and selling houses in the secondary market, which has hindered the pace of transformation from material resources toliquidity. Therefore, the relevant regularory authorities should establish a complete opening information secondary system.
Ensure the openness of information, so that both buyers and sellers can receive accurate information in time and safeguard the interests of both parties.

What's more, we should also lower transaction costs for the secondary market moderately, the relevant regulatory authorities lower transaction costs of the housing market in moderately to encourage urban residents to consume and reduce the housing price pressure of residents. Meanwhile, we should also strengthen the construction of the credit system of the secondary market, severe punishment for bad behavior, ensures the healthy operation of the estate secondary market, establish an estate secondary market with strong trading activity and perfect information circulation.

\section{REFERENCE}

[1] Tang Zhijun, Hui Jun Xu, BA, Research of how china's real estate market fluctuation influence on macroeconomic fluctuatio, Statistical research, 2(2010) 44-47.

[2] Li and Yao, The wealth effect of the real estate market theory and empirical research, Statistical, 12(2007).

[3] SheinerL, housing Prices and the Savings of Renters, Journal of LrbanL, conomics, 1(1995) 38.

[4] Milton Friedman, A Statistical Illusion in Judging Keynesian Models, Journal of Political Economy, 65(1957) 64 75.

[5] Luo Zuoyan, Housing expenditure, housing prices, wealth effect and consumption growth Discussion of monetary policy on asset price fluctuations ,Finance and economic science, 5(2010).

[6] Du Li, Pan Chunyang, Zhang Suyu, CaiJiangnan,Will the rise of house price promote or restrain the resident consumption -- Based on the empirical study of panel data of 172 prefecture level cities in China, Zhejiang social science, 8(2010).

[7] Ge Yang, Xu Jiajun, The influence of income gap on China's real estate wealth effect, Modern economic research, 3(2011) .

[8] Wang Huilong, Gao Bo, Empirical analysis of real estate price fluctuation and consumption in the Yangtze River Delta, Industry economics research, 1(2011).

[9] Li Xiangqian, Tan Xiaofen, GuoQiang, Impact of real estate price on consumption in China Based on the oretical and empirical study, Modern finance and Economics, 2(2012).

[10] [Chen Bin, Li Tao, Family fixed assets, wealth effect and household consumption: Empirical Evidence from Chinese urban families, Economic research, 3(2014).

[11] Lu biao, the relation between the rise of housing prices and Chinese consumer wealth effect or dcrowding out effect,Southwestern University of Finance and Economics, 4(2014). 